\title{
Media comic math berbasis whiteboard annimation dalam pelajaran matematika
}

\author{
Rica Wijayanti ${ }^{1}$, Buaddin Hasan ${ }^{1}$, Rishi Kumar Loganathan ${ }^{2}$ \\ ${ }^{1}$ Program Studi Pendidikan Matematika, Sekolah Tinggi Keguruan dan Ilmu Pendidikan PGRI \\ Bangkalan. Jalan Soekarno Hatta No. 52, Mlajah Balangkalan 69116, Indonesia. \\ ${ }^{2}$ School Improvement Specialist Coaches (SISC), WDT 22, 90200 Kinabatangan, Sabah, Malaysia \\ * Corresponding Author. E-mail: buaddinhasan@stkippgri-bkl.ac.id \\ Received: 5 April 2018; Revised: 20 April 2018; Accepted: 30 April 2018
}

\begin{abstract}
Abstrak
Media comic math berbasis wihiteboard animation ini bertujuan untuk mempermudah guru dalam memberikan materi pelajaran matematika. Disamping itu, media comic math ini diharapkan mampu memotivasi siswa untuk belajar lebih aktif dalam rangka pengembangan media pembelajaran matematika untuk memperkuat karakter positif peserta didik dalam memahami konsep matematika dengan memanfatkan ilmu pengetahuan dan teknologi. Penelitian ini adalah Research and Development $(R \& D)$. Penelitian ini menggunakan metode adalah uji coba produk yang dilakukan dalam beberapa tahap, yaitu: (1) Analisis Potensi dan Masalah, (2) Pengembangan, tahap pengembangan dilakukan berupa mendesain produk media pembelajaran dan validasi desain produk. (3) Tahap Ujicoba Produk, tahap uji coba produk dilakukan untuk mengetahui kelayakan produk dan efektifitas hasil belajar. Teknik pengumpulan data menggunakan teknik angket, wawancara, dan tes. Penelitian ini menggunkan dua teknik analisis data, yaitu teknik analisis statistik deskriptif dan analisis deskriptif kualitatif. Hasil penelitian menunjukan bahawa media comic math berbasis whiteboard animation layak untuk digunakan dalam proses pembelajaran matematika disekolah. Dan pembelajaran menggunakan media comic math berbasis whiteboard animation pada materi geometri bangun datar sangat efektif.
\end{abstract}

Kata Kunci: media pembelajaran, comic math, whiteboard animation.

\section{Comic math media based on whiteboard animation in math}

\begin{abstract}
Comic math media based wihiteboard animation is expected to facilitate teachers in delivering mathematics lessons. In addition, this media is expected to motivate students to learn more actively in order to develop the media of learning mathematics to strengthen the positive character of learners in understanding the concept of mathematics by utilizing science and technology. This research is Research and Development $(R \& D)$. The method used is product trial, done in some stage, among others: (1) Potential Analysis Stage and Problem, (2) Development Stage, development stage done in the form of product instructional media design and product design validation. (3) Stage of Product Testing, product trial stage is performed to determine the feasibility of the product and the effectivnesse learning outcome. Data collection in this study using questionnaires, interviews, and tests. In this study used two data analysis techniques, namely descriptive statistical analysis techniques and qualitative descriptive analysis. The results showed that comic math media based on whiteboard animation is feasible for use in the process of learning mathematics in school. And learning using comic math media based on whiteboard animation on flat wake geometry material is very effective.
\end{abstract}

Keywords: learning media, comic math, whiteboard animation.

How to Cite: Wijayanti, R., Hasan, B., \& Loganathan, R. (2018). Media comic math berbasis whiteboard annimation dalam pelajaran matematika. Jurnal Riset Pendidikan Matematika, 5(1), 53-63. doi:http://dx.doi.org/10.21831/jrpm.v5i1.19207

Permalink/DOI: http://dx.doi.org/10.21831/jrpm.v5i1.19207 


\section{Jurnal Riset Pendidikan Matematika, 5 (1), 2018 - 54}

Rica Wijayanti, Buaddin Hasan, Rishi Kumar Loganathan

\section{PENDAHULUAN}

Dalam belajar matematika, seseorang dituntut untuk menyiapkan mentalnya pada saat penerimaan informasi baru yang ditandai dengan tindakan nyata melalui pemecahan masalah matematika. Dalam mengajar matematika guru dapat merangsang siswanya mencapai pemahaman dalam belajar melalui pendekatan belajar yang tepat dan pemilihan media yang sesuai sehingga hasil belajar siswa semakin baik. Dalam prosesnya guru harus mampu merencanakan pembelajaran dengan baik sebagai upaya untuk mencapai hasil belajar yang diinginkan.

Kegiatan pembelajaran merupakan proses komunikasi yang bersifat interaksi timbal balik, baik antara guru dengan siswa atau siswa dengan siswa yang lain untuk mencapai indikator pembelajaran yang telah ditetapkan secara efektif. Dalam proses belalar siswa diperlakukan sebagai subjek utama, sedangkan guru sebagai pemandu untuk menciptakan suasana pembelajaran yang baik, hal ini diharapkan dapat mempermudah dalam mendidik siswa untuk mencapai tujuan pembelajaran secara maksimal. selain itu, dengan adanya perkembangan teknologi kegiatan pembelajaran dapat dimaksimalkan dan dikembangkan menggunakan media pembelajaran yang sesuai, sehingga siswa mudah menerima materi yang diajarkan.

Proses penyampaian meteri dari guru kepada siswa perlu adanya suatu media dengan tujuan dapat mempermudah siswa dalam memahami materi. Terdapat banyak jenis media pembelajaran yang dapat dimanfaatkan oleh guru dalam penyampaian materi pelajaran. Menurut Webcrawler (2013) educational media refer to channel of communication that carry message with an instructional puspuse. They are usually utilised for the sole purpuse of learning and teaching. Media yang digunakan bisa bervariasi, dapat disesuaikan dengan materi dan karakteristik siswa.Educational media such as print media, non-print media and electronic media (Omodara \& Adu, 2014).

Menurut Smaldino (2011) media pembelajaran mempunyai peran dalam penyampaian materi yang tersedia dengan melibatkan spesialis teknologi atau media dan mensurvei panduan referensi sumber dan media dengan mengubah materi yang ada dan merancang materi baru. Maka dari itu, guru harus bisa menentukan dan mengembangkan media pembelajaran untuk mempermudah dalam mentranfer materi kepada siswa.
Media pembelajaran mempunyai peran yang sangat penting dalam proses belajar mengajar, pada kegiatan tersebut materi yang kurang jelas dapat dibantu penyampaiannya dengan menggunakan media sebagai alat bantu. Kesulitan bahan ajar dapat dikurangi dengan alat bantu media pembelajaran. Media pembelajaran dapat mempermudah apa yang kurang mampu guru sampaikan melalui penjelasan. Media pembelajaran dapat menjadikan hal yang abstrak menjadi lebih konkret. sehingga siswa lebih mudah memahami materi pelajaran daripada tanpa menggunakan media pembelajaran.

Media menjadi sarana yang sangat dibutuhkan oleh guru dalam menciptakan proses belajar yang baik. Proses belajar yang baik merupakan salah satu penentu keberhasilan proses belajar mengajar. Media dapat diartikan sebagai the storage of visuals and their display on television-type screen (Smaldino, 2011). Media pembelajaran dimaksudkan untuk mebantu guru dalam mengirim pesan, informasi, atau materi pelajaran kepada siswa. Sehingga dapat mempermudah siswa dalam memahami materi pelajaran.

Menurut AECT (Association for Educational Communications and Tecnology) (1977) teknologi mutahir sebagai konsep media pembelajaran diartikan sebagai "instruktional technology is the theory of design, development, utilitazion, management and evaluation of processes and resources for learning" (Kurt, 1977). Peran utama media pembelajaran adalah membantu dalam penyampaian materi pada proses belajar serta memberikan kemudahan baik bagi guru maupun siswa dengan fasilitas media. Pemberian media belajar tersebut dilakukan dengan cara mendesain, mengembangkan, dan menilai proses belajar dengan memanfaatkan media pembelajaran berbasis teknologi informasi dan komunikasi.

Namun pada pelaksanaannya proses pembelajaran dikelas kurang memanfaatkan media dalam penyampaiannya. Dalam pembelajaran guru menyampaikan materi sebagai proses transfer pengetahuan dari guru kepada siswa bersifat teacher centered, konvensional, dan masih belum ada kreasi dan inovasi media yang digunakan dalam proses penyampaian materi. Hal ini yang menjadikan siswa kurang tertarik bahkan merasa bosan berada di dalam kelas. Waktu yang kurang untuk belajar di kelas maupun kurangnya pemahaman terhadap materi menyebabkan siswa kurang memahami materi yang diberikan oleh guru. Sehingga perlu adanya 
kreatifitas guru untuk merancang dan mendesain media pembelajaran dengan memanfaatkan media berbantuan komputer. Pembelajaran menggunakan media berbantuan animasi komputer lebih aktif dan efektif (Talib, Matthews, \& Secombe, 2005). Penggunaan media interaktif berbantuan media TIK dapat meningkatkan pengetahuan siswa, studi menunjukkan the result that use power point based screencast omatic videos can increase interest in learning, as well as the easy absorption of the material so that it can improve student learning outcomes teaching elementary mathematics (Hasan, 2017).

Media pembelajaran yang baik harus dapat membantu guru dalam mentransfer ilmu pengetahuan dan juga mampu mempermudah peserta didik dalam memahami materi pelajaran. Seiring dengan perkembangan jaman dan perkembangan ilmu pengetahuan dan teknologi media pembelajaran juga harus mengikuti perkembangan tersebut. Dalam penelitian ini, peneliti mengembangkan media pembelajaran comic math berbasis whiteboard animation dengan tujuan untuk mengembangkan media pembelajaran matematika, yaitu media comic math berbasis whiteboard animation. Kemudian melakukan analisa keefektifan media pembelajaran comic math berbasis whitboard animation dalam pembelajaran matematika.

Pengertian tentang komik dikemukakan oleh Mardiono (1998, p. 3) komik merupakan susunan gambar bercerita dan memberikan pesan-pesan pembacanya. Komik secara keseluruhan merupakan ilustrasi cerita utuh antara gambar dan tulisan. Sebagian dari komik membuat penekanan sesuai dengan karakteristik siswa sehingga mampu memperbanyak alur cerita, baik dari segi wujud, ilustrasi, maupun unsur imajinasi. Komik dapat dikatakan media yang unik.

Komik memadukan antara tulisan dan gambar dalam bentuk yang kreatif. Animasi gambar yang sederhana ditambah dengan katakata membuat komik dapat digemari oleh semua kalangan. Jadi komik dapat menjadi media alternatif yang tepat digunakan dalam pembelajaran, keterlibatan emosional pembaca sangat mempengaruhi pola pikir dan daya ingat terhadap informasi yang diterima.

Sebagaimana dikatakan Sudjana \& Rivai (2011) bahwa komik mempunyai peran dalam pengajaran untuk meningkatkan minat belajar para peserta didik. Pemberian pengalaman belajar yang menarik dapat meningkatkan hasil belajar siswa. Selain itu, peemanfaatan komik dalam pembelajaran membuat proses belajar mengajar lebih menyenangkan yang berakibat pada motivasi belajar siswa menjadi lebih meningkat. Selanjutnya penelitian tentang model pembelajaran yang menggunakan komik sebagai media pemebalajaran dilakukan oleh Wahyudi (2010) diperoleh hasil bahwa pencapaian ranah afektif dalam pembelajaran dengan penerapan model pembelajaran berbasis komik pada anak berkesulitan belajar sangat signifikan. Sedangkan menurut Daryanto (2013, p. 27) komik menyediakan cerita yang sederhana, mudah ditangkap dan dipahami isinya sehingga sangat digemari oleh anak-anak ataupun orang dewasa.

Agar komik dapat dikatakan sebagai media pembelajaran maka isi cerita komik harus memenuhi unsur pembelajaran, dengan kata lain komik tidak hanya menyediakan aspek hiburan. Media komik juga harus memenuhi indikator materi yang diajarkan dari setiap materi yang diceritakan, yaitu memuat materi pembelajaran sesuai dengan pokok bahasan materi yang akan diberikan.

Komik sebagai media pembelajaran yang edukatif, memiliki sifat yang sederhana, jelas, dan mudah dipahami. Komik merupakan suatu alur cerita yang mengungkapkan sebuah imajinasi dan bercerita dalam urutan yang yang saling berkaitan, dengan memadukan antara gambar dan tulisan yang dirancang untuk memberikan hiburan kepada para pembaca. Komik mempunyai peranan secra instruksional dalam menciptakan daya tarik siswa untuk belajar (Ahmad, 2014, pp. 77-79).

Desain dan pengembangan untuk membuat media pembelajaran komik berbasis teknologi adalah upaya pengembangan media pembelajaran matematika yang perlu diaplikasikan dalam proses pengajaran. Pengembangan media pembelajaran harus disesuaikan dengan karakteristik siswa dan perkembangan jaman. Salah satunya adalah media pembelajaran komik matematika yang dikembangkan dengan aplikasi whiteboard animation. Pemanfaatan media whiteboard animation memberikan pengaruh positif terhadap sikap siswa dalam belajar matematika (Erbas, Ince, \& Kaya, 2015, pp. 299312). Menurut Gillen, Littleton, Twiner, Staarman, \& Mercer (2008, pp. 348-358) pembelajaran menggunakan media whiteboard animation secara efektif dapat membantu guru dalam proses penyemapaian materi. Media interaktif whiteboard animation telah banyak dikembangkan dan dimanfaatkan dalam penyampaian 
informasi, presentasi dan juga penyampaian materi pelajaran. Whiteboard animation dalam penelitian ini menggunakan sparkol videoscribe. Media ini menggunakan animasi bergerak yang disertai gambar dan keterangan. Media ini menjadi lebih menarik tergantung dari kreatifitas pengembang.

Media whiteboard animation berupa video interaktif yang didesain berisi tentang materi pelajaran. Pemanfaatan whiteboard animation dalam pembelajaran sangat efektif, hal ini dikarenakan semua konten dalam video merupakan manipulasi dari guru yang disesuaikan dengan karakter siswa dan konten materi yang akan diajarkan.

Sanaky (2011) menuliskan beberapa kelebihan pembelajaran menggunakan animasi video, antara lain: (1) media video menyajikan objek belajar secara nyata atau pesan pembelajaran secara realistik, sehingga sangat baik untuk menambah pengalaman belajar, (2) media animasi video mempunyai daya tarik tersendiri sehingga dapat menjadi pemacu atau memotivasi pembelajar untuk belajar, (3) media video sangat efektif untuk mencapai tujuan belajar psikomotor, (4) media video dapat mengurangi kebosanan belajar.

Penelitian tentang pemanfaatan media interactive whiteboard telah banyak dilakukan oleh peneliti. Salah satunya penelitian oleh Bahadur(2013) yang menyatakan bahwa media interactive whiteboard sangat efektif digunakan sebagai media pembelajaran di kelas. Kemudian menurut Manny-Ikan, Dagan, Tikochinski, \& Zorman(2011) pembelajaran dengan media interactive whiteboard menjadikan motivasi siswa lebih baik dan hasil belajar semakin meningkat, guru juga lenih meningkatkan kemampuan dalam mengembangkan pembelajaran. Menurut Akbaş \& Pektaş (2011) pemanfaatan whiteboard animation dalam pembelajaran menjadikan siswa lebih antusias dalam belajar, tingkat partisipasi siswa meningkat dibandingkan dengan pembelajaran biasa, dan juga pemahaman konsep lebih efektif. Sedangkan penelitian Koçak \& Gülcü (2013) menyebutkan bahwa pembelajaran menggunakan media whiteboard guru dapat menyelesaikan kesulitan yang dialami siswa dalam menerima meteri pelajaran. Dari beberapa penliti tersebut, para peneliti hanya mengembangkan media whiteboard berbasis materi presentasi pelajaran. peneliti masih belum mengembangkan dengan madukan alur cerita yang cocok dengan karakter siswa. Sehingga perlu dikembangakan media pembel- ajaran matematika menggunakan alur cerita (comic math) dengan animasi berbasis whiteboard yang disesuaikan dengan tingkatan atau karakteristik siswa.

Sejalan dengan perkembangan jaman dan ilmu pengetahuan dan teknologi. Media pembelajaran juga harus dapat menyesuaikan dengan perkembangan tersebut. Media pembelajaran yang dikembangkan dalam penelitian ini berupa media comic math berbasis whiteboard animation. Media ini dikembangkan dengan memperhatikan karakteristis siswa dalam proses pembelajaran dan perkembangan ilmu pengetahuan dan teknologi. Media ini dirancang dengan menggunakan software whiteboard animation dengan memadukan animasi bergerak, alur cerita (konsep materi), dan gambar.

Pengembangan media pembalajaran comic math dirancang dengan menggunakan softwarewhiteboard animation dengan memadukan animasi bergerak, alur cerita (konsep materi), dan gambar. Hasil dari pengembangan media comic math berbasis whiteboard animation berupa video pembelajaran setiap sesion yang selanjutnya di-upload di akun youtube yang di-hiperlink menjadi sebuah aplikasi pembelajaran pada sistem android. Sehingga media comic math berbasis whiteboard animation ini dapat membantu guru dalam menjelaskan materi pelajaran matematika dan siswa juga akan lebih senang dan mudah dalam memahami materi sehingga berdampak pada prestasi belajar siswa yang semakin membaik. Maka dari itu pada penelitian ini, peneliti pengembangkan media comic math berbasis whiteboard animation sebagai media pembelajaran matematika di sekolah.

Pengembangan media pembelajaran comic math berbasis whiteboard animation ini menghasilkan suatu produk berupa media pembelajran matematika yang kreatif, inovatif, modern sesuai dengan perkembangan IPTEK dan sesuai dengan karakteristik siswa sehingga dapat memberikan alternatif bagi guru dalam pemilihan media pembelajaran yang tepat. Selain itu media comic math berbasis whiteboard animation ini dapat membantu guru dalam menjelaskan materi pelajaran.

\section{METODE}

Penelitian ini merupakan penelitian pengembangan atau Research and Development $(R \& D)$. Penelitian dan pengembangan adalah metode penelitian yang dirancang untuk 
menghasilkan sebuah produk, dan menguji keefektifan produk tersebut (Sugiyono, 2015).

Proses pengambilan data dilakukan pada bulan Januari 2018 di SMP Negeri 1 Socah yang beralamatkan di Jalan Ki Hajar Dewantara No. 5 Socah Kabupaten Bangkalan.

Dalam penlitian ini peubah yang diukur adalah kelayakan dan keefektifan media pembelajaran comic math berbasis whiteboard animation. Pengukuran dilakukan dengan uji coba produk. (1) uji coba ahli perancangan media pembelajaran, pada tahap ini yang menjadi subjek adalah seorang dosen yang memiliki kualifikasi S-2 dan kompetensi di bidang perancangan media pembelajaran, (2) uji coba ahli di bidang isi, yang menjadi subjek dalam bidang isi adalah 1 orang dosen matematika dan 1 guru matematika, (3) uji coba kelas, pada uji coba kelas subjeknya adalah siswa kelas VIII SMP Negeri 1 Socah, uji coba siswa dilakukan dalam tiga tahapan. Tahap petama uji perorangan, yaitu terdiri atas 6 orang siswa sebagai subjek uji coba. Uji coba perorangan dilakukan dengan tujuan untuk mengetahui keterbacaan media komik. Tahap kedua uji coba kelompok kecil, yaitu terdiri atas 12 orang siswa sebagai subjek uji coba. Uji coba kelompok kecil dilakukan dengan tujuan untuk mengetahui kelayakan media untuk digunakan dalam pembelajaran. Sedangkan tahap ketiga adalah uji coba lapangan (kelas), pada tahap ini terdapat 36 siswa sebagai subjek. Uji coba kelas ini bertujuan untuk mengetahui respon siswa terhadap media comic math berbasis whiteboard animatioan dan efektifitas media comic math berbasis whiteboard animation dalam pembelajaran yang dilakukan dengan menggunakan angket dan pretestposttest. Adapun prosedur pengembangan produk dapat dilihat pada Tabel 1.

\section{Data, Intrumen, dan Teknik Pengumpulan Data}

Data yang digunakan adalah data kuantitif dan data kualitatif. Sedangkan instrumen yang digunakan berupa lembar angket, instrumen wawancara dan instrumen tes. Pengumpulan data menggunakan teknik angket, wawancara, dan tes. Angket bertujuan untuk mengumpulkan data hasil validasi dari ahli isi, ahli rancangan media, dan guru bidang studi matematika serta uji produk. Teknik angket ini dilengkapi dengan instrumen berupa format angket.

Wawancara merupakan suatu bentuk berkomunikasi verbal atau semacam percakapan yang bertujuan untuk memperoleh informasi (Nasution, 2004). Format wawancara bersifat bebas dan berstruktur (pertanyaan sudah dirumuskan terlebih dahulu). Teknik wawancara dilengkapi dengan instrumen berupa format wawancara. Untuk mengukur hasil belajar digunakan teknik tes sebelum (pretest) dan sesudah (posttest) menggunakan media comic math berbasisi whiteboard animation.

\section{TeknikAnalisis Data}

Peneliti menggunakan dua teknik analisis data yaitu analisis statistik deskriptif dan analis data deskriptif kualitatif. Analisis statistik deskriptif digunakan untuk mengolah data yang diperoleh melalui angket dalam bentuk deskripsi persentase. Teknik analisis deskriptif kualitatif ini digunakan untuk mengolah data hasil validasi ahli isi mata pelajaran, ahli rancangan media pembelajaran, siswa, dan guru bidang studi matematika. Teknik analisis data dilakukan dengan mengelompokkan informasi yang diperoleh dari data kualitatif baik data masukan, kritik, dan saran perbaikan yang terdapat pada angket dan hasil wawancara. Hasil analisis data ini kemudian digunakan sebagai acuan peneliti untuk merevisi produk untuk mencapai kelayakan.

Tabel 1. Tabel Prosedur Pengembangan

\begin{tabular}{ccc}
\hline Subjek Coba & Uji Ahli Produk & Pengumpula Data \\
\hline Ahli rancangan media & Draf Analisis Revisi & Angket, Konsultasi \\
Ahli isi materi pelajaran & Uji Coba Perorangan & \\
6 orang siswa & Analisis, Revisi & Angket, Wawancara \\
& Uji Coba Kelompok Kecil & \\
12 orang siswa & Analisis, Revisi & Angket, Wawancara \\
& Uji Coba Lapangan & Angket, Wawancara \\
Siswa kelas V III & Analisis, Revisi & \\
Hasil Produk (media comic math berbasis whiteboard animation)
\end{tabular}


Jurnal Riset Pendidikan Matematika, 5 (1), 2018 - 58

Rica Wijayanti, Buaddin Hasan, Rishi Kumar Loganathan

Tabel 2.Kriteria Penilaian Produk Pengembangan

\begin{tabular}{ccc}
\hline Tingkat Pencapaian & Kualifikasi & Keterangan \\
\hline $91 \%-100 \%$ & Sangat baik & Tidak perlu direvisi \\
$81 \%-90 \%$ & Baik & Tidak perlu direvisi \\
$71 \%-80 \%$ & Cukup & Direvisi \\
$61 \%-70 \%$ & Kurang & Direvisi \\
$0 \%-60 \%$ & Sangat Kurang & Direvisi \\
\hline
\end{tabular}

Untuk menghitung persentase dari masing-masing subjek menggunakan rumus:

$$
\text { Persentase }=\frac{\left.\sum \text { (Jawaban } \mathrm{x} \text { bobot tiap pilihan }\right)}{n \times \text { bobot tertinggi }} \times 100 \%
$$

Keterangan:

$\sum=$ jumlah jawaban $\mathrm{x}$ bobot tiap pilihan

$n=$ jumlah seluruh item angket

Sedangkan, untuk menghitung persentase

keseluruhan subjek, rumus yang digunakan adalah:

Prosentase $=\frac{P}{N} \times 100 \%$

Keterangan:

$\mathrm{P}=$ jumlah persentase keseluruhan subjek

$\mathrm{N}=$ banyak subjek

Untuk dapat menyimpulkan dan pengambilan keputusan perlu atau tidak dilakukan perbaikan produk pengembangan digunakan ketetapan melalui kriteria penilaian produk pengembangan, ditunjukkan pada Tabel 2.

Setelah semua data penelitian terkumpul, langkah selanjutnya dilakukan beberapa teknik analisis data yaitu uji normalitas, dan uji homogenitas, serta uji hipotesis. Untuk uji normalitas dilakukan dengan menggunakan tes chi kuadrat. Uji ini dimaksudkan untuk mengetahui populasi yang dipilih pada penelitian ini berdistribusi normal atau tidak. Teknik analisis data yang kedua adalah uji homogenitas yang dilakukan dengan menggunakan uji-F. Uji ini bertujuan untuk mengetahui apakah varian data kedua kelompok yang diteliti mempunyai varian yang homogen atau tidak homogen. Sedangkan uji terakhir yang digunakan adalah uji hipotesis dengan menggunakan bantuan uji t-test. Setelah proses analisis data dilakukan, maka peneliti akan menyimpulkan efektif atau tidaknya penggunaan media pembelajaran comic math berbasis whiteboard animation.
Analisis statistik deskriptif digunakan untuk mengolah data dari hasil pre-test dan hasil post-test, hal ini bertujuan untuk mengethaui tingkat keefektifan produk yang dihasilkan sebagai indikator untuk mengetahui pemahaman konsep materi diajarkan melalui pembelajaran menggunakan media comic math berbasis whiteboard animation.

Analisis statistik deskriptif menggunakan teknik uji $t$ (produk moment) sebagai berikut:

$$
\mathrm{t}=\frac{M d}{\sqrt{\frac{\sum x^{2} d}{N(N-1)}}}(\text { Arikunto, 2010, p. 261) }
$$

Penjelasan:

$\mathrm{Md}=$ mean dari perbedaan antara pre-test dengan post-test

$\sum x^{2} d=$ jumlah kuadrat deviasi

$\mathrm{N}=$ subjek dalam sampel

\section{HASIL DAN PEMBAHASAN}

\section{Media Comic Math Berbasis Whiteboard Animation}

Berikut ini dipaparkan hasil penilaian ahli bidang isi mata pelajaran matematika terhadap produk pengembangan berupa media comic math menggunakan metode kuesioner dengan instrumen angket.

Hasil validasi ahli isi mata pelajaran yang berkenaan dengan media comic math berbasis whiteboard animation adalah sebagai berikut: pertama, perlu dicek kembali konsistensi penulisan, bagian yang penting perlu diberi tanda khusus atau bold. Kedua, kesesuaian ilustrasi gambar perlu disesuaikan dengan karakter siswa agar lebih menarik.

Untuk menindaklanjuti masukan, saran, dan komentar ahli perangan media yang berkenaan dengan media pembelajaran comic math berbasis whiteboard animation adalah dengan melakukan revisi media 
Jurnal Riset Pendidikan Matematika, 5 (1), 2018 - 59

Rica Wijayanti, Buaddin Hasan, Rishi Kumar Loganathan

Tabel 3. Hasil Angket Penilaian Ahli Perancang Media Pembelajaran terhadap Media Comic Math Berbasis Whiteboard Animation

\begin{tabular}{clc}
\hline No. & \multicolumn{1}{c}{ Kriteria } & Skor \\
\hline 1. & Ketepatan judul dalam mempresentasikan isi & 4 \\
2. & Kejelasan cek kemampuan untuk mempermudah memahami materi & 3 \\
3. & Kejelasan uraian materi pada tiap kegiatan belajar & 4 \\
4. & Kejelasan contoh-contoh soal pada media & 4 \\
5. & Kesesuaian antara ilustrasi, tulisan dan materi pelajaran & 3 \\
6. & Kesesuaian pemilihan animasi dengan karakter siswa & 4 \\
7. & Kesesuaian soal uji kompetensi dengan konsep yang dipelajari & 4 \\
8. & Keterkaitan tugas dalam bentuk kerja dalam kegiatan kelompok yang diberikan dengan materi & 4 \\
& \multicolumn{1}{c}{ Jumlah } & 31 \\
\hline
\end{tabular}

Tabel 4. Hasil Penilaian Ahli Isi Mata Pelajaran terhadap Media Pembelajaran

\begin{tabular}{|c|c|c|}
\hline No. & Kriteria & Skor \\
\hline 1. & Kesesuaian judul bab dengan uraian materi & 4 \\
\hline 2. & $\begin{array}{l}\text { Kejelasan deskripsi pendahuluan untuk mendorong keingintahuan siswa untuk belajar lebih } \\
\text { lanjut }\end{array}$ & 3 \\
\hline 3. & $\begin{array}{l}\text { Kesesuaian rumusan kompetensi (SK dan KD) dengan isi paparan materi pada setiap kegiatan } \\
\text { belajar }\end{array}$ & 3 \\
\hline 4. & Kejelasan indikator menggambarkan perolehan hasil belajar yang dapat diukur & 4 \\
\hline 5. & Ketepatan pembuatan rencana belajar untuk mencapai hasil belajar yang maksimal & 4 \\
\hline 6. & $\begin{array}{l}\text { Kestrukturan contoh-contoh soal pada tiap kegiatan belajar bisa meningkatkan pemahaman } \\
\text { siswa }\end{array}$ & 3 \\
\hline 7. & Ketepatan contoh soal pada media & 4 \\
\hline 8. & $\begin{array}{c}\text { ketepatan soal uji kompetensi dengan konsep yang dipelajari } \\
\text { Jumlah }\end{array}$ & $\begin{array}{c}4 \\
29\end{array}$ \\
\hline
\end{tabular}

Hasil angket penilaian Ahli Isi perancangan media pelajaran yang tercantum pada Tabel 3 , maka dapat dihitung persentase tingkat keberhasilan media pembelajaran sebagai berikut:

Presentase $=\frac{\sum \text { Jawaban } \times \text { bobot tiap pilihan }}{n \times \text { bobot tertinggi }} \times 100 \%$

Karena bobot tiap pilihan adalah 1 , sehingga persentase hasil perhitungan $=30:(8 \mathrm{x}$ 4) $\mathrm{x} 100 \%=93,75 \%$. Setelah dikonversikan menggunakan tabel konversi, persentase tingkat pencapaian adalah $93,75 \%$, pencapaian ini berada pada kategori sangat baik, maka media pembelajaran comic math berbasis whiteboard animation ini tidak perlu direvisi.

Berikut ini dipaparkan hasil penilaian oleh ahli isi mata pelajaran matematika terhadap produk pengembangan melalui metode kuesioner dengan instrumen angket.

Saran ahli isi mata pelajaran berkenaan dengan media comic math berbasis whiteboard animation pembelajaran adalah sebagai berikut: Pertama, perlu dilihat lagi konsistensi penulisan, materi pelajaran pada komik. Kedua, animasi gambar perlu disesuaikan dengan karakteristik siswa. Dan ketiga, contoh-contoh soal lebih divariasikan lagi.
Masukan dan saran tertulis ahli isi mata pelajaran matematika digunakan sebagai bahan pertimbangan untuk memperbaiki media pembelajaran. Masukan-masukan tentang isi materi media comic math berbasis whiteboard animation dapat memperkaya isi paparan materi media pembelajaran matematika.

Hasil angket tentang uji ahli isi materi adalah $=29:(8 \times 4) \times 100 \%=90,6 \%$. Setelah dikonversikan menggunakan tabel konversi, persentase mencapai 90,6\%, dengan kata lain berada pada kategori sangat baik, maka isi materi pada media pembelajaran comic math berbasis whiteboard animation ini tidak perlu direvisi.

\section{Uji Coba Perorangan}

Draf II merupakan produk hasil pengembangan yang telah diperbaiki sesuai pendapat ahli isi mata pelajaran dan ahli rancangan media pembelajaran, langkah selanjutnya media diberikan kepada enam orang siswa untuk dilakukan uji coba secara perorangan. Keenam siswa diminta untuk menilai media pembelajaran comic math berbasis whiteboard animation. Pada uji coba perorangan ini untuk memperoleh informasi tentang keterbacaan media pembelajaran oleh siswa sebagai subjek penelitian. Aspekaspek pertanyaan dalam angket uji coba per- 
orangan meliputi kesalahan pengetikan, penggunaan kata yang sulit dipahami sehingga membutuhkan penjelasan khusus, kemudian kesalahan penggunaan tanda baca, kesalahan dalam penggunaan huruf awalan, huruf kecil dan huruf kapital, hal lain yang berkaitan dengan keterbacaan media, serta kesesuaian dengan karakteristik siswa. Berdasarkan indikator tersebut, uji coba perorangan berkaitan dengan penggunaan bahasa dan ilustrasi gambar yang menarik.

Adapun data dari hasil uji coba perorangan terhadap media comic math berbasis whiteboard animation adalah: pertama, media comic math berbasis whiteboard animation ini bagus dan menarik keterbacaan mudah dipahami oleh siswa. Kedua, media ini sudah bagus, ilustrasi gambar sesuai dengan karakter siswa namun harus lebih baik lagi dalam memberikan warna yang menarik, sehingga siswa akan lebih menarik dalam membacanya.

Draf III produk pengembangan, dari hasil uji coba sebekumnya, selanjutnya media diberikan kepada 12 orang siswa untuk dilakukan uji kelompok kecil. Uji kelompok kecil bertjuan (1) untuk mengidentifikasi permasalahan yang timbul pada saat pembelajaran, (2) untuk mengetahui efektifitas media pada uji perorangan, dan (3) menentukan apakah media dapat digunakan untuk belajar secara mandiri. Pengujian ini menekankan kepada kelayakan proses belajar mengajar menggunakan media comic math berbasis whiteboard animation.

Rerata persentase media pembelajaran comic math berbasis whiteboard animation yaitu $82,05 \%$. Hal ini menunjukkan bahwa media comic math berbasis whiteboard animation berada dalam kualifikasi baik.

\section{Uji Coba Lapangan}

Selanjutnya, produk menjadi draf IV yang merupakan hasil pengembangan berdasarkan saran dan masukan siswa dalam uji kelompok kecil, kemudian dilakukan uji kelas. Uji kelas atau lapangan dilaksanakan di SMP Negeri 1 Socah Kabupaten Bangkalan. Siswa yang dijadikan responden uji coba adalah siswa kelas VIII B yang berjumlah 36 orang. Hasil uji lapangan dan revisi disajikan dalam Tabel 5.

Rerata persentase angket penilaian siswa terhadap media pembelajaran comic math berbasis whiteboard animation pada uji kelas mencapai $80,2 \%$, hal ini berarti media pembelajaran berada pada kategori baik. Ada beberapa saran dan komentar yang diberikan oleh siswa dan guru yang dituliskan dalam angket, kemudian dijadikan bahan petimbangan oleh peneliti untuk proses penyempurnaan media comic math berbasis whitboard animation.

Tabel 5. Data Hasil Responden Uji Lapangan

\begin{tabular}{|c|c|c|c|}
\hline No. & Aspek Penilaian & Skor & Persentase \\
\hline 1. & $\begin{array}{l}\text { Bagaimanakah isi } \\
\text { materi pada media ini? }\end{array}$ & 115 & 80 \\
\hline 2. & $\begin{array}{l}\text { Bagaimanakah } \\
\text { kesesuaian ilustrasi } \\
\text { gambar? }\end{array}$ & 115 & 80 \\
\hline 3. & $\begin{array}{l}\text { Apakah contoh soal } \\
\text { pada media ini dapat } \\
\text { membantu saudara? }\end{array}$ & 118 & 82 \\
\hline 4. & $\begin{array}{l}\text { Bagaimanakah tingkat } \\
\text { keterbacaan rangkuman } \\
\text { pada bagian akhir bab } \\
\text { pada media ini? }\end{array}$ & 121 & 84 \\
\hline 5. & $\begin{array}{l}\text { Bagaimana urutan } \\
\text { penyajian materi pada } \\
\text { setiap ilustrasi gambar }\end{array}$ & 108 & 75 \\
\hline & Jumlah Skor & 115,5 & 80,2 \\
\hline
\end{tabular}

Siswa merasa senang dan tampak antusias mengikuti pelajaran matematika menggunakan media comic math. Siswa dengan penuh semangat memahami materi yang ada pada media comic math berbasis whiteboard animation. Sama halnya dengan hasil wawancara kepada bebrapa siswa terhadap penggunaan media comic math, mayoritas siswa merasa senang belajar dengan bantuan media ini karena pembelajaran dengan media comic math berbasis whiteboard animation baru pertama kali dilaksanakan di SMP Negeri 1 Socah. Selain itu tampilan comic math berbasis whiteboard animation membuat mereka tertarik untuk mempelajari materi, karakteristik dan ilustrasi gambar sesuai dengan tingkatan siswa, adapula sebagian dari subjek meminta dilakukan pengembangan media comic math berbasis whiteboard animation pada semua pelajaran matematika.

Rata-rata angket penilaian terhadap media pembelajaran comic math berbasis whiteboard animation dalam uji lapangan adalah $25 /(4 \times 7) \mathrm{x}$ $100 \%=89 \%$, dimana persentase itu menunjukkan bahwa media pembelajaran tersebut berkualifikasi baik.

Nilai pretest dan pretest dijadikan bahan pertimbangan untuk mengetahui tingkat pemahaman yang diperoleh siswa setelah proses pembelajaran menggunakan media comic math berbasis whitebard animation. Untuk proses analisis peneliti menggunakan teknik uji $t$ dengan rumus: 
$\mathrm{t}=\frac{M d}{\sqrt{\frac{\sum x^{2} d}{N(N-1)}}}($ Arikunto, 2010, p. 261)

$\mathrm{Md}=$ mean dari perbedaan antara pre-test dengan post-test

$\sum x^{2} d=$ jumlah kuadrat deviasi

$\mathrm{N}=$ subjek dalam sampel

\section{Proses Analisis Data}

Tabel 6. Nilai Pretest dan Posttest

\begin{tabular}{ccccc}
\hline No & Pre & Post & $\begin{array}{c}\text { Gain } \boldsymbol{d} \\
\text { (posttest- } \\
\text { pretest })\end{array}$ & $\mathbf{d}^{2}$ \\
\hline $\mathrm{N}=36$ & $\frac{1288}{X_{1}}$ & $\frac{2792}{X_{1}}$ & $\sum d=1514$ & $\sum d^{2}=$ \\
& $=$ & $=$ & & 68532 \\
& 35,78 & 77,56 & & \\
\hline
\end{tabular}

$\mathrm{Md}=\frac{\sum d}{N}=\frac{1514}{36}=42,06$

$\sum x^{2} d=\sum d^{2}-\frac{\left(\sum d\right)^{2}}{N}$

$=68532-\frac{1514^{2}}{36}$

$=68532-63672,11=4859,89$

$\mathrm{t}=\frac{M d}{\sqrt{\frac{\sum x^{2} d}{N(N-1)}}}$

$=\frac{42,06}{\sqrt{\frac{4859,89}{36(36-1)}}}$

$=\frac{42,06}{\sqrt{\frac{4859,89}{1260}}}$

$=\frac{42,06}{\sqrt{3,857}}$

$=21,415$

d.b. $\quad=\mathrm{N}-1=36-1=35$

(hasil kesesuaian pada tabel nilai t)

Dengan $\mathrm{t}_{0,05}$ harga $\mathrm{t}=1,69$ sehingga $t$ hitung $>\mathrm{t}$ tabel (sangat signifikan)

Dengan demikian pembelajaran dengan menggunakan media comic math berbasis whiteboard animation dapat dikatakan efektif.

\section{Diskusi Pembahasan}

Berdasarkan hasil penelitian, dapat dikatakan bahwa media comic math berbasis white- board animation dari segi isi materi sesuai dengan tingkat pengetahuan siswa, kemudian jika dilihat dari segi desain atau rancangan media, media comic math berbasis whiteboard animation sesuai dengan karakteristik siswa dan perkembangan ilmu pengetahuan, media ini memberikan ilustrasi yang menarik terhadap materi yang diajarkan, sehingga siswa lebih tertarik dalam belajar, hal ini senada dengan Daryanto (2013, p. 27) yang menyatakan bahwa anak-anak ataupun orang dewasa mengemari komik, karena komik menyediakan cerita yang sederhana dan mudah dipahami. Kemudian juga pendapat (Akbaş \& Pektaş, 2011) pemanfaatan whiteboard animation dalam pembelajaran menjadikan siswa lebih antusias dalam belajar, tingkat partisipasi siswa meningkat dibandingkan dengan pembelajaran biasa, dan juga pemahaman konsep lebih efektif.

Sedangkan dalam segi penggunaan media pembelajaran comic math berbasis whiteboard animation dalam pembelajaran matematika sangat efektif. Tingkat partisipasi siswa semakin baik. Hal ini sependapat dengan Bahadur (2013) yang menyatakan bahwa media interactive whiteboard sangat efektif digunakan sebagai media pembelajaran di kelas. Begitu pula pendapat Manny-Ikan et al. (2011) bahwa pembelajaran dengan media interactive whiteboard menjadikan motivasi siswa lebih baik dan hasil belajar semakin meningkat, guru juga lebih meningkatkan kemampuan dalam mengembangkan media pembelajaran.

\section{SIMPULAN DAN SARAN}

\section{Simpulan}

Dalam proses pembelajaran seseorang belajar dengan menanggapi dan memproses informasi yang diperoleh. Sehingga menghasilkan perubahan baik tingkah laku maupun kemampuan berpikir dan kemampuan menalar.

Dengan metode pembelajaran yang sesuai dengan karakteristik dan kebutuhan, siswa lebih bersemangat untuk belajar. Sama halnya dengan pemanfaatan media komik dalam pembelajaran. Media komik dapat menjadi alat bantu dalam penyampaian materi karena lebih efektif dan efisien dalam penggunaannya serta sesuai dengan karakteristik dan kebutuhan siswa.

Comic Math berbasis whiteboard animation merupakan alat yang mempunyai fungsi menyampaikan materi pelajaran dengan menggabungkan cerita (materi pelajaran) dengan ilustrasi animasi yang bergerak. Media comic 
math berbasis whiteboard animation dapat dijadikan sumber belajar dalam proses pembelajaran di era teknologi seperti sekarang ini. Dalam hal ini, media comic math berbasis whiteboard animation berfungsi sebagai media menyampaian materi pelajaran yang efektif. Jika dilihat dari aspek fungsi pengembangan komik pembelajaran, akan terlihat sesuatu yang sulit dapat dibuat lebih menyenangkan dan menarik. Penggunaan media comic math berbasis whiteboard animation dalam proses pembelajaran dapat mempermudah siswa dalam memahami materi yang disampaikan oleh guru.

Berdasarkan hasil penelitian pengembangan media pembelajaran matematika comic math berbasis whiteboard animation layak untuk digunakan dalam proses pembelajaran matematika di sekolah, karena memliki karakteristik sesuai dengan tingkatan siswa dan mempunyai ketertarikan sehingga peserta didik lebih giat untuk belajar.

Sedangkan untuk kefektifan media comic math berbasis whiteboard animation dalam pembelajaran dapat disimpulkan bahwa pemanfaatan media comic math berbasis whiteboard animation memiliki dampak yang baik terhadap prestasi belajar siswa. Sehingga dapat dikatakan bahwa pembelajaran dengan memanfaatkan media comic math berbasis whiteboard animation sangat efektif dalam pembelajaran matematika.

\section{Saran}

Pengembangan media pembelajaran comic math berbasis whiteboard animation ini masih sebatas pada materi geometri bangun datar, maka dari itu perlu pengembangan pada materi-materi yang lain serta juga perlu memperhatikan ilustrasi gambar yang lebih menarik sesuai dengan karakter siswa.

Terimakasih kepada DRPM Kemenristekdikti yang telah membiayai penelitian ini dalam Hibah Penelitian Dosen Pemula tahun pendanaan 2018.

\section{DAFTAR PUSTAKA}

Ahmad, R. (2014). Media Intruksional Edukatif. Jakarta: Rineka Cipta.

Akbaş, O., \& Pektaş, H. M. (2011). The effects of using an interactive whiteboard on the academic achievement of university students. In Asia-Pacific Forum on Science Learning and Teaching (Vol. 12, pp. 1-19). Hong Kong: The Education University of Hong Kong, Department of
Science and Environmental Studies.

Arikunto, S. (2010). Prosedur penelitian: Suatu pendekatan praktik. Jakarta: Rineka Cipta.

Bhadur, G. K. A (2013) Intercative whiteboard for primary school in mathematic An effective tool or just another trend? International Journal of Education and development Using ICT, 9(1). Retrieved from

http://ijedict.dec.uwi.edu/viewarticle.php? $\mathrm{id}=1559$

Daryanto, D. (2013). Media pembelajaran: Peranannya sangat penting dalam mencapai tujuan pembelajaran. Yogyakarta: Gava Media.

Erbas, A. K., Ince, M., \& Kaya, S. (2015). Learning mathematics with interactive whiteboards and computer-based graphing utility. Educational Technology \& Society, 18(2), 299-312. Retrieved fromhttps://www.jets.net/ETS/journals/18 _2/22.pdf

Gillen, J., Littleton, K., Twiner, A., Staarman, J. K., \& Mercer, N. (2008). Using the interactive whiteboard to resource continuity and support multimodal teaching in a primary science classroom. Journal of Computer Assisted Learning, 24(4), 348-358. https://doi.org/10.1111/j.13652729.2007.00269.x

Hasan, B. (2017). Teaching elementary mathematics using power point based screencast $O$-Matic videos. INA-Rxiv. https://doi.org/10.17605/OSF.IO/728V9

Koçak, Ö., \& Gülcü, A. (2013). Teachers' remarks on interactive whiteboard with LCD panel technology. International Journal of Education in Mathematics Science and Technology, 1(4), 294-300.

Kurt, S. (1977). Definitions of educational technology. Retrieved May 14, 2018, from

https://educationaltechnology.net/definitio ns-educational-technology/

Manny-Ikan, E., Dagan, O., Tikochinski, T. B., \& Zorman, R. (2011). Using the interactive white board in teaching and learning - An evaluation of the SMART CLASSROOM pilot project. Interdisciplinary Journal of E-Learning and Learning Objects, 7. Retrieved from 


\section{Jurnal Riset Pendidikan Matematika, 5 (1), 2018 - 63}

Rica Wijayanti, Buaddin Hasan, Rishi Kumar Loganathan

http://www.openu.ac.il/research_center/ch ais2011/papers.html

Mardiono, T. (1998). Empat belas (14) jurus membuat komik. Jakarta: Creative Media.

Nasution, S. (2004). Berbagi Pendekatan dalam proses belajar dan mengajar. Jakarta: PT. Bina Aksara

Omodara, O. D., \& Adu, E. I. (2014). Relevance of educational media and multimedia technology for effective service delivery in teaching and learning processes. IOSR Journal of Research \& Method in Education Ver. I, 4(2), 48-51. Retrieved from www.iosrjournals.org

Sanaky. H. A.H. (2011). Media pembelajaran buku pegangan wajib guru dan dosen Yogyakarta; Kaukaba Dipantara

Smaldino, S. E. (2011). Instructional tecnology and media for learning. dalam the association for educational communication and tecnology. Jakarta: Kencana.

Sudjana, N., \& Rivai, A. (2011). Media pengajaran. Bandung: Sinar Baru Algensindo.

Sugiyono. (2015). Metode penelitian pendidikan: Pendekatan kuantitatif, kualitatif, dan $R \& D$. Bandung: Alfabeta.

Talib, O., Matthews, R., \& Secombe, M. (2005). Computer-animated instruction and students' conceptual change in electrochemistry: Preliminary qualitative analysis. International Education Journal, ERC2004 Special Issue, 5(5), 29-42. Retrieved from http://iej.cjb.net

Wahyudi, A. (2010). Model pembelajaran berbasis komik untuk mencapai ranah afektif pada pendidikan kewarganegaraan bagi anak berkesulitan belajar. Jurnal Pendidikan Dan Kebudayaan, 16(7), 43. https://doi.org/10.24832/jpnk.v16i7.507

Webcrawler, C. (2013). Definition of educational media. Retrieved from http://www.ask.com/question/meaningofeducational-media 